\title{
Fresh and Composted Paper Sludges Sustain Soil Productivity
}

\author{
Adrien N'Dayegamiye, Anne Drapeau, and Cargèle Nduwamungu \\ Research and Development Institute for the Agri-Environment (IRDA), 2700 Einstein, Complexe Scientifique, D.1.110, \\ Quebec, Qc, Canada G1P $3 W 8$
}

Correspondence should be addressed to Adrien N’Dayegamiye, adrien.ndaye@irda.qc.ca

Received 7 December 2009; Accepted 4 April 2010

Academic Editor: Stephen Herbert

Copyright ( 2010 Adrien N’Dayegamiye et al. This is an open access article distributed under the Creative Commons Attribution License, which permits unrestricted use, distribution, and reproduction in any medium, provided the original work is properly cited.

\begin{abstract}
In this 5-yr study, application frequency of fresh (FDS) and composted (CDS) paper sludges was evaluated on soil properties and silage corn (Zea mays L.) and barley (Hordeum vulgare L.) yields and N uptake by comparing one application (2000) with repeated applications $(2000,2001,2002)$. Treatments consisted of a control with neither amendment nor $\mathrm{N}$ fertilizer, a recommended $\mathrm{N}$ rate for corn $\left(160 \mathrm{~kg} \mathrm{Nha}^{-1}\right)$ and barley $\left(90 \mathrm{~kg} \mathrm{Nha}^{-1}\right)$, and FDS and CDS at a rate of $40 \mathrm{Mgha}^{-1}$ on wet basis with or without reduced $\mathrm{N}$ fertilizer $\left(120 \mathrm{~kg} \mathrm{Nha}^{-1}\right)$ on corn. Compared to the control, the FDS or CDS applications significantly increased the proportions of soil larger macroaggregates $(>2 \mathrm{~mm})$ and the mean-weight diameter (MWD) of aggregates, regardless their application frequency. Single or three yrs additions of FDS or CDS produced, on average, an increase of 25 to $31 \%$ of the soil $\mathrm{C}$ and $\mathrm{N}$ contents compared to the control and the recommended $\mathrm{N}$ fertilizer treatment $\left(160 \mathrm{~kg} \mathrm{Nha}^{-1}\right)$. In the first year of their application, the FDS or CDS with or without supplemental $\mathrm{N}$ fertilizer $\left(120 \mathrm{~kg} \mathrm{~N} \mathrm{ha}^{-1}\right)$ reduced silage corn and $\mathrm{N}$ uptake, compared to the control probably due to $\mathrm{N}$ immobilization. However, silage corn yields were increased in the following years with one application or with repeated application of FDS or CDS. Results show that benefits on soil properties and crop yields of single application of FDS and CDS were similar to those of the triple applications and were still noticeable a few years following the last application.
\end{abstract}

\section{Introduction}

Environmental concerns associated with wastes management have led to new technologies in paper mill industries since 1997 for recycling used papers and deinking paper sludges were consequently produced. Those paper sludges are extracted in two phases as described by N'Dayegamiye [1]. Fine debris are initially separated from the mixture in a sedimentation basin to produce the primary sludge, followed by extraction in a second basin where the water soluble fibers are digested by the microorganisms to produce the secondary sludge. Mineral fertilizers (N, P, and K) are generally added in the second basin to stimulate microorganism growth and activity.

Primary paper sludges from de-inking paper mill plant have high $\mathrm{C} / \mathrm{N}$ ratios $(>200)$ and they induced $\mathrm{N}$ immobilization and reduced crop yields [2]. When primary and secondary de-inking paper sludges are mixed, the mixed paper sludges obtained have lower $\mathrm{C} / \mathrm{N}$ ratios (30 to 40) making this mixture more attractive for agricultural use as organic amendments. Composts are also produced from those mixed paper sludges. Although paper sludges and their composts are largely available, their use in agriculture is still low due to the high cost associated to their acquisition and their application to the soils. However, the use of these organic materials may sustain crop yields and soil productivity in intensive cropping systems which leave low organic residues on the soil $[3,4]$. The utilization of paper sludges as source of both plant nutrients and organic matter to improve soil structure is of high interest to maintain soil productivity $[5,6]$ particularly in low $\mathrm{C}$ input rotation systems.

Improvement of soil structure and increase of soil $\mathrm{C}$ content after application of paper sludges could depend on the partition of their organic carbon in the labile and stable $\mathrm{C}$ pools. Their effects on soil aggregation and $\mathrm{C}$ accumulation rate depend not only on the quantity but also on the quality of the organic wastes. Those effects are linked to the rates at which the organic wastes are decomposed by soil microorganisms and therefore to their capacity to stimulate the soil microflora and to produce humic substances $[7,8]$. 
Soil aggregation results from intermediate products that form during decomposition as polysaccharides, microbial products along with phenolic and humic substances $[9,10]$.

Paper sludges are known as lignin-rich organic material that resist against mineralization [11] and therefore contribute to increase the soil organic matter content $[1,8,12]$. Paper sludges may also have a long-lasting effect on soil structure [13] and fertility than some animal manure which generally induce short-term improvement due to their high mineralization potential as shown by Darwish et al. [14].

Applications of paper sludges and vegetable residues with high $\mathrm{N}$ contents and $\mathrm{C}: \mathrm{N}$ ratios of $12-25$ have shown a net $\mathrm{N}$ mineralization and this contributed to better wheat and corn nutrition and yields $[1,6,15]$. However, mixed de-inking paper sludges generally have low $\mathrm{N}$ content and high $\mathrm{C}: \mathrm{N}$ ratios $(>30)$ which may reduce crop growth, yields and $\mathrm{N}$ nutrition [2] due to $\mathrm{N}$ immobilization by soil microorganisms during their decomposition. Therefore, their applications to the soil should be supplemented with $\mathrm{N}$ fertilizer to meet crop $\mathrm{N}$ needs.

Increases in crop yields and $\mathrm{N}$ uptake following the applications of paper sludges may not strictly depend on $\mathrm{N}$ availability, but also on the improvement of the soil physical and biological properties as demonstrated by N'Dayegamiye $[1,6]$. Soils with improved soil structure benefit from increased gas exchanges, along with better water infiltration and retention in the upper horizons $[16,17]$. In addition, the various macropores between soil aggregates provide niches for soil microorganisms, increasing biological and enzyme activities in the soil [6] and consequently nitrogen and phosphorus mineralization and availability [18]. The improvements in the soil properties resulting from inputs of organic wastes lead to a gradual increase in crop yields $[4,19,20]$.

For fresh paper sludges with low $\mathrm{C} / \mathrm{N}$ ratios and high $\mathrm{N}$ contents, frequent application to agricultural soils was recommended to achieve aggregate stability, to increase soil $\mathrm{C}$ content, and to sustain soil microbial growth and activity [6]. However, Grandya et al. [13] reported that there were residual effects of cull potato compost and beef cattle manure on soil physical properties and concluded that their regular addition on the soil may not be needed.

For paper sludges with low $\mathrm{N}$ contents and high $\mathrm{C} / \mathrm{N}$ ratios, little information exists on their short-term and residual effects on crop yields and $\mathrm{N}$ uptake, and on their lasting effect on soil properties. Because regular application of paper sludges and their composts may not be feasible, it is important to assess their lasting effects on soil properties and crop yields. The objective of this study was to evaluate the effect of one or three successive applications of FDS and CDS on soil aggregate stability and density, soil total $\mathrm{N}$ and $\mathrm{C}$ contents in a clay loam under a low $\mathrm{C}$ input rotation system (i.e., silage corn and barley). Their short-term and residual effects on silage corn and barley yields and $\mathrm{N}$ nutrition were also assessed.

\section{Materials and Methods}

2.1. Site Description and Experimental Design. This study was conducted from 2000 to 2004 on a Le Bras clay loam (sandy over clayey, mixed, nonacid, frigid, Typic Humaquept) situated at the IRDA research station in Saint-Lambert-deLauzon, Québec, Canada. The soil texture in the A horizon $(0-20-\mathrm{cm})$ consisted of $330 \mathrm{~g}$ sand $\mathrm{kg}^{-1}, 470 \mathrm{~g} \mathrm{silt} \mathrm{kg}^{-1}$, and

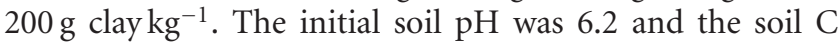
and $\mathrm{N}$ contents were $16.5 \mathrm{~g} \mathrm{C} \mathrm{kg}^{-1}$ and $1.4 \mathrm{~g}$ total $\mathrm{N} \mathrm{kg}^{-1}$, respectively. The soil available $\mathrm{P}, \mathrm{K}, \mathrm{Ca}$, and $\mathrm{Mg}$ contents were, respectively, of 50,103,1195, and $98 \mathrm{mg} \mathrm{kg}^{-1}$.

Mixed de-inking paper sludges were collected from the Stadacona paper mill plant (Québec, Canada) that recycles used papers. Primary and secondary paper sludges were mixed at the ratio of $1.5: 1$ (i.e., $60 \%$ and $40 \%$ of the mixed FDS consisted of primary and secondary paper mill sludges, resp.). Over six months composted FDS were obtained from Les Composts du Québec inc. (Québec, Canada).

The FDS and CDS properties are presented in Table 1. Organic C content ranged from 264 to $344 \mathrm{~g} \mathrm{C} \mathrm{kg}^{-1}$, and total $\mathrm{N}$ from 7.2 to $11.3 \mathrm{~g} \mathrm{~N} \mathrm{~kg}^{-1}$. Organic $\mathrm{C}$ and total $\mathrm{N}$ contents were lower for CDS, compared to FDS. The FDS and $\mathrm{CDS} C / \mathrm{N}$ ratios were, on average, superior to 30 and $\mathrm{pH}$ from 6.0 to 8.1. The FDS and CDS contained macro- and micronutrients at variable levels and heavy metal contents were generally low.

The experimental design was a split-plot, with 6 treatments as main plot and application frequency (single versus triple) as subplot. The treatments included FDS and CDS at a rate of $40 \mathrm{Mg} \mathrm{ha}^{-1}$ on a wet basis, with or without reduced $\mathrm{N}$ fertilizer $\left(120 \mathrm{~kg} \mathrm{~N} \mathrm{ha}^{-1}\right)$, recommended $\mathrm{N}$ fertilizer rate $\left(160 \mathrm{~kg} \mathrm{Nha}^{-1}\right)$ for corn and an unamended, unfertilized control. All treatments were replicated three times. The six treatments in three replicates were installed on plots of $10 \mathrm{~m}$ $\times 12 \mathrm{~m}$. In the second and third year of the experiment, the plots were split to study single application of FDS and CDS in 2000, and their triple applications in 2000, 2001, and 2002 on corn yields and $\mathrm{N}$ uptake. The subplots were 5 - $\mathrm{m}$ wide $\times$ 12-m long.

The applications of FDS and CDS were made manually at a rate of $40 \mathrm{Mg} \mathrm{ha}^{-1}$, on wet basis. The $\mathrm{N}$ fertilizer was broadcast applied $\left(160 \mathrm{~kg} \mathrm{Nha}^{-1}\right)$ as ammonium $\mathrm{N}$ $\left(\mathrm{NH}_{4} \mathrm{NO}_{3}\right)$. In the plots with single or triple applications of FDS and CDS with supplemental $\mathrm{N}$ fertilizer, $\mathrm{N}$ fertilizer rate was added at $120 \mathrm{~kg} \mathrm{Nha}^{-1}$ as ammonium nitrate in 2000, 2001, and 2002. All the plots including the control received $60 \mathrm{~kg} \mathrm{P}_{2} \mathrm{O}_{5} \mathrm{ha}^{-1}$ and $100 \mathrm{~kg} \mathrm{~K}_{2} \mathrm{O} \mathrm{ha}^{-1}$ to ensure that these two major elements would not be limiting for corn growth.

In 2003 and 2004, the applications of FDS and CDS were stopped in order to assess their residual effects on crop yields and $\mathrm{N}$ uptake. Except for the complete $\mathrm{N}$ fertilizer rate treatment, all the plots received $120 \mathrm{~kg} \mathrm{~N} \mathrm{ha}^{-1}$, $60 \mathrm{~kg} \mathrm{P}_{2} 0_{5} \mathrm{ha}^{-1}$, and $100 \mathrm{~kg} \mathrm{~K}_{2} \mathrm{O} \mathrm{ha}^{-1}$ for silage corn in 2003 and $60 \mathrm{~kg} \mathrm{Nha}^{-1}, 60 \mathrm{~kg} \mathrm{P}_{2} 0_{5}$, and $80 \mathrm{~kg} \mathrm{~K}_{2} \mathrm{O} \mathrm{ha}^{-1}$ for barley in 2004. The complete $\mathrm{N}$ fertilizer rate treatment received $160 \mathrm{~kg} \mathrm{Nha}^{-1}$ for silage corn and $90 \mathrm{~kg} \mathrm{Nha}^{-1}$ for barley.

The organic wastes and mineral fertilizer were incorporated into the soil by disc harrowing in the $0-15 \mathrm{~cm}$ soil layer. Crop sequence included silage corn from 2000 to 2003 and barley in 2004. From 2000 to 2003, all plots were cropped to silage corn (var. Hyland, HL-S009; 2250 Corn Heat Units) at a rate of 89000 plants ha ${ }^{-1}$. Barley (Legend $\mathrm{cv}$ ) was seeded 
TABLE 1: Selected properties of fresh (FDS) and composted (CDS) paper sludges.

\begin{tabular}{|c|c|c|c|c|c|c|}
\hline \multirow{3}{*}{ Property $^{\dagger}$} & \multicolumn{6}{|c|}{ Application Periods } \\
\hline & \multicolumn{2}{|c|}{ Spring 2000} & \multicolumn{2}{|c|}{ Fall 2000} & \multicolumn{2}{|c|}{ Fall 2001} \\
\hline & FDS & $\mathrm{CDS}$ & FDS & CDS & FDS & $\mathrm{CDS}$ \\
\hline Dry weight $\left(\mathrm{g} \mathrm{kg}^{-1}\right)$ & 369 & 370 & 280 & 400 & 363 & 406 \\
\hline $\mathrm{pH}\left(\mathrm{H}_{2} \mathrm{O} 1: 1\right)$ & 7.45 & 8.14 & 7.4 & 6.8 & 6.07 & 7.01 \\
\hline Organic $\mathrm{C}\left(\mathrm{g} \mathrm{kg}^{-1}\right)$ & 344 & 264 & 334 & 281 & 335 & 253 \\
\hline Total N $\left(\mathrm{g} \mathrm{kg}^{-1}\right)$ & 8.0 & 7.8 & 11.3 & 7.6 & 7.2 & 5.9 \\
\hline $\mathrm{C}: \mathrm{N}$ ratio & 43 & 34 & 25 & 32 & 47 & 43 \\
\hline $\mathrm{P}\left(\mathrm{g} \mathrm{kg}^{-1}\right)$ & 0.78 & 0.74 & 1.15 & 1.15 & 1.03 & 1.39 \\
\hline $\mathrm{K}\left(\mathrm{g} \mathrm{kg}^{-1}\right)$ & 0.55 & 0.59 & 0.65 & 0.99 & 0.55 & 1.01 \\
\hline $\mathrm{Ca}\left(\mathrm{g} \mathrm{kg}^{-1}\right)$ & 29.2 & 24.1 & 30.8 & 23.6 & 34.0 & 27.2 \\
\hline $\operatorname{Mg}\left(\mathrm{g} \mathrm{kg}^{-1}\right)$ & 0.76 & 1.27 & 0.71 & 1.64 & 0.91 & 1.77 \\
\hline $\mathrm{B}\left(\mathrm{mg} \mathrm{kg}^{-1}\right)$ & n.d. & n.d. & 7 & 13 & 2.8 & 7.2 \\
\hline $\mathrm{Cu}\left(\mathrm{mg} \mathrm{kg}^{-1}\right)$ & 130 & 86 & 154 & 115 & 177 & 237 \\
\hline $\mathrm{Fe}\left(\mathrm{mg} \mathrm{kg}^{-1}\right)$ & 1320 & 4025 & 1001 & 6704 & 1106 & 6312 \\
\hline $\operatorname{Mn}\left(\mathrm{mg} \mathrm{kg}^{-1}\right)$ & 84 & 224 & 93 & 266 & 88 & 249 \\
\hline $\mathrm{Zn}\left(\mathrm{mg} \mathrm{kg}^{-1}\right)$ & 98 & 315 & n.d. & n.d. & 124 & 305 \\
\hline $\operatorname{Mo}\left(\mathrm{mg} \mathrm{kg}^{-1}\right)$ & n.d. & n.d. & 5 & 5 & 4.5 & 2.4 \\
\hline $\mathrm{Cr}\left(\mathrm{mg} \mathrm{kg}^{-1}\right)$ & 23 & 71 & 12 & 52 & 11.5 & 11.2 \\
\hline $\mathrm{Co}\left(\mathrm{mg} \mathrm{kg}^{-1}\right)$ & 1.6 & 2.3 & 1.0 & 2.0 & 3.2 & 33.7 \\
\hline
\end{tabular}

${ }^{\dagger}$ Elements listed are expressed on dry weight basis.

n.d. $=$ not detected.

at $160 \mathrm{~kg} \mathrm{ha}^{-1}$. After each harvest, the residues of silage corn and barley were removed from all plots as this is a normal practice in the region.

2.2. Analytical Methods. The FDS and CDS were subsampled at the time of application and kept at $4{ }^{\circ} \mathrm{C}$ until analysis. Samples were dried at $70^{\circ} \mathrm{C}$ for dry matter determination ( $\mathrm{g}$ dry sample, $\mathrm{kg}^{-1}$ fresh sample). The dry samples were then ground to pass through a $0.25-\mathrm{mm}$ sieve prior to chemical analysis. The $\mathrm{pH}$ was determined using dried sample in a FDS or CDS-water mixture $(1: 1 ; \mathrm{g}: \mathrm{mL})$. Organic $\mathrm{C}$ and total $\mathrm{N}$ contents were determined by dry combustion using a LECO C-N 1000 analyser (Leco Corp., St-Joseph, MI). Phosphorus, $\mathrm{K}, \mathrm{Ca}$, and $\mathrm{Mg}$ were extracted by digestion in $\mathrm{H}_{2} \mathrm{SO}_{4}$ and $\mathrm{H}_{2} \mathrm{SeO}_{3}$ with addition of $\mathrm{H}_{2} \mathrm{SO}_{4}$ for $1 \mathrm{~h}$ at $400^{\circ} \mathrm{C}$ [21], while $\mathrm{B}, \mathrm{Cu}, \mathrm{Fe}, \mathrm{Mn}, \mathrm{Zn}, \mathrm{Mo}, \mathrm{Cr}$, and Co were extracted by dry ashing at $450^{\circ} \mathrm{C}$ for $3 \mathrm{~h}$ followed by ash treatment with $\mathrm{HCl}$ [22]. The content of the different elements in the extracts were determined by inductively plasma optical emission spectrometer (PerkinElmer 4300 DV, Boston, MA).

Soil samples were collected to a depth of $0-20-\mathrm{cm}$ at the initiation of the experiment in 2000 and in 2004 after barley harvest. In each experimental unit, six soil cores were taken randomly with a $2-\mathrm{cm}$ diameter stainless auger (Oakfield model B, Oakfield Apparatus Company, WI), bulked to make a composite sample, sieved at $2-\mathrm{mm}$ in the field, and air dried to determine soil $\mathrm{pH}$, texture, and $\mathrm{P}, \mathrm{K}, \mathrm{Ca}$, and $\mathrm{Mg}$ contents.
Air-dried subsamples were ground to $<0.5 \mathrm{~mm}$ and used to determine the soil $\mathrm{C}$ and $\mathrm{N}$ contents.

Soil sampling was also made in fall 2004 after 5 yrs of the experimentation to assess physical properties. Two intact soil cores per plot $(6.5-\mathrm{cm}$ height $\times 6.5-\mathrm{cm}$ diam. $)$ were collected to determine bulk density. One intact soil block of about $600 \mathrm{~g}$ was taken in each plot with a spade to a depth of 0 $20-\mathrm{cm}$, taking care to avoid soil compression, to assess water stable aggregates. The soil blocks were sieved at $8-\mathrm{mm}$ in the field and kept at $4^{\circ} \mathrm{C}$ until analysis.

Soil $\mathrm{pH}$ was measured in $1: 1$ soil/water solution. Extractable $\mathrm{P}, \mathrm{K}, \mathrm{Ca}$, and $\mathrm{Mg}$ were determined in a Mehlich III solution [23] and measured on inductively coupled plasma optical emission spectrometer Perkin Elmer 4300 DV, Boston, MA, USA (Model AAII, Technicon Instruments, Tarytown, NY). The soil C and $\mathrm{N}$ contents were determined by dry combustion using a Leco C-N 1000 analyzer. The soil at the experimental site was assumed nonlimestone $(\mathrm{pH}=$ 6.8), therefore the total $\mathrm{C}$ content was assumed to be organic C. The $\mathrm{C}$ content on an area basis $\left(\mathrm{MgC} \mathrm{ha}^{-1}\right)$ was computed as in Foley and Cooperband [5] using soil layers of $10-\mathrm{cm}$ (i.e., $0-10-\mathrm{cm}$ and $10-20 \mathrm{~cm}$ ) and the measured bulk density for each soil layer.

Water-stable macroaggregates (WSA) were determined by the wet-sieving method. Forty grams of air-dried soil $(>6 \mathrm{~mm})$ were put on the top of a series of sieves $(5,2$, 1 , and $0.25-\mathrm{mm}$ ) and the sieves were immersed in water and shaken for $10 \mathrm{~min}$. The soil fractions recovered on each 
TABLE 2: Residual effects of applications of fresh and composted paper sludges, and $\mathrm{N}$ fertilizer on soil water-stable aggregates in 2004.

\begin{tabular}{|c|c|c|c|c|c|}
\hline \multirow[t]{2}{*}{ Treatments } & \multicolumn{4}{|c|}{ Aggregates (\%) } & \multirow[t]{2}{*}{$\mathrm{MWD}^{\dagger} \mathrm{mm}$} \\
\hline & $>5 \mathrm{~mm}$ & $2-5 \mathrm{~mm}$ & $2-1 \mathrm{~mm}$ & $1-0.25 \mathrm{~mm}$ & \\
\hline \multicolumn{6}{|l|}{ Frequency (single application $^{+}$) } \\
\hline Control & 29.42 & 23.35 & 2.79 & 5.92 & 2.62 \\
\hline $\mathrm{N}$ fertilizer $\left(160 \mathrm{~kg} \mathrm{~N} \mathrm{ha}^{-1}\right)$ & 32.35 & 21.03 & 2.13 & 3.05 & 2.89 \\
\hline FDS & 34.94 & 23.04 & 2.36 & 3.20 & 3.13 \\
\hline CDS & 36.78 & 26.35 & 1.96 & 2.79 & 3.0 \\
\hline $\mathrm{FDS}+120 \mathrm{~kg} \mathrm{Nha}^{-1}$ & 30.12 & 26.53 & 3.10 & 4.36 & 2.96 \\
\hline $\mathrm{CDS}+120 \mathrm{~kg} \mathrm{~N} \mathrm{ha}^{-1}$ & 32.32 & 26.07 & 2.07 & 2.94 & 2.92 \\
\hline \multicolumn{6}{|l|}{ Frequency (triple application ${ }^{+++}$) } \\
\hline Control & 27.15 & 21.42 & 6.01 & 8.99 & 2.51 \\
\hline $\mathrm{N}$ fertilizer $\left(160 \mathrm{~kg} \mathrm{~N} \mathrm{ha}^{-1}\right)$ & 32.99 & 21.78 & 1.92 & 2.99 & 2.95 \\
\hline FDS & 36.33 & 22.57 & 2.99 & 3.67 & 3.16 \\
\hline CDS & 36.15 & 23.24 & 2.52 & 3.03 & 3.22 \\
\hline $\mathrm{FDS}+120 \mathrm{~kg} \mathrm{Nha}^{-1}$ & 31.84 & 21.72 & 3.25 & 4.49 & 3.10 \\
\hline $\mathrm{CDS}+120 \mathrm{~kg} \mathrm{~N} \mathrm{ha}{ }^{-1}$ & 31.71 & 25.68 & 3.07 & 1.75 & 3.07 \\
\hline \multicolumn{6}{|l|}{ ANOVA F values } \\
\hline Treatments & $4.88^{*}$ & $3.87^{*}$ & $8.41^{* *}$ & $6.60^{* *}$ & $5.54^{*}$ \\
\hline Frequency & 0.56 & 0.29 & 1.99 & 0.24 & 0.75 \\
\hline Treatments $\times$ Frequency & 0.99 & 1.71 & 2.47 & 1.34 & 0.67 \\
\hline \multicolumn{6}{|l|}{ Contrasts } \\
\hline (1) Control versus others & $8.76^{* *}$ & $10.04^{* *}$ & $16.68^{* *}$ & $12.20^{* *}$ & $9.62^{* *}$ \\
\hline (2) $\mathrm{N}$ fert. versus FDS and CDS & 0.00 & 2.20 & $8.82^{* *}$ & 2.89 & 0.30 \\
\hline (3) FDS versus CDS & 0.48 & 0.12 & $7.14^{*}$ & $8.95^{* *}$ & 1.35 \\
\hline (4) $\mathrm{FDS}^{\ddagger}$ versus FDSN ${ }^{\S}$ & 2.14 & 0.69 & 3.36 & $6.71^{*}$ & 0.33 \\
\hline (5) $\mathrm{CDS}^{\Uparrow}$ versus $\mathrm{CDSN}^{\#}$ & 0.03 & 2.30 & $6.03^{*}$ & 2.23 & 0.10 \\
\hline
\end{tabular}

$*{ }^{* *}=.05$ and .01 probability levels of statistically significant difference, respectively.

${ }^{\dagger}$ MWD, mean-weight diameter (unit: $\mathrm{mm}$ ) of soil aggregates.

${ }^{\ddagger} \mathrm{FDS},{ }^{\S} \mathrm{FDSN}$ : fresh paper sludges alone or with $\mathrm{N}$ fertilizer, respectively.

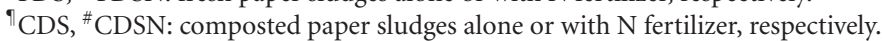

${ }^{+},{ }^{++}$: Single and triple: one application in 2000, and three successive applications in 2000, 2001, and 2002, respectively.

sieve were dried at $65^{\circ} \mathrm{C}$ for $24 \mathrm{~h}$, corrected for sand and expressed as a percentage of total dry soil [24]. Aggregate mean weight diameter (MWD) was calculated according to Haynes and Beare [25]. Soil bulk density was determined using the cylinder method [26].

2.3. Crop Yields and $N$ Uptake. The two innermost rows of silage corn of each plot were harvested in late autumn. Entire corn plants were cut at the soil surface, chopped, weighed, and a 600 -g to $800-\mathrm{g}$ subsample was dried at $60^{\circ} \mathrm{C}$ and weighed again for dry matter calculations. Barley grain was harvested and measured and a subsample (200-g) dried at $60^{\circ} \mathrm{C}$ and weighed to determine the dry matter grain yield. The $\mathrm{N}$ content of corn tissues and barley grain was determined by digestion in $\mathrm{H}_{2} \mathrm{SO}_{4}$ and $\mathrm{H}_{2} \mathrm{SeO}_{3}$ with the addition of $\mathrm{H}_{2} \mathrm{SO}_{4}$ for $1 \mathrm{~h}$ at $400^{\circ} \mathrm{C}$ [21] and total $\mathrm{N}$ content analyzed on an Automated Technicon Autoanalyzer. Silage corn and barley grain $\mathrm{N}$ uptake was calculated as the product of tissue $\mathrm{N}$ concentration and dry matter yield.

2.4. Statistical Analysis. Data on macroaggregates proportions, mean-weight diameter of stable aggregates, density, total $\mathrm{N}$ and $\mathrm{C}$ content and $\mathrm{C}$ per hectare, crop yields, and $\mathrm{N}$ uptake were subjected to a two-way analysis of variance (ANOVA) using the SAS GLM procedure [27] for a splitplot design. Contrast analysis was used to test the differences among means.

\section{Results and Discussion}

3.1. Soil Aggregate Stability. Application of FDS, CDS, or $\mathrm{N}$ fertilizer significantly increased soil macroaggregates $(>2 \mathrm{~mm})$ and the mean-weight diameter of aggregates, compared to the unamended, unfertilized control (Table 2; contrast 1). As in this study, Chantigny et al. [28] and Bipfubusa et al. [29] indicated that paper sludges applications rapidly increased soil macroaggregates proportions and stability. Compared to the control, the application of FDS or CDS contributed to the formation of larger macroaggregates ( $>5 \mathrm{~mm}$ and $2-5 \mathrm{~mm}$ ) probably due to the increase of organic binding agents that form macroaggregates such as polysaccharides, microbial products, phenolic substances, and humic substances $[10,30]$ Surprisingly, $\mathrm{N}$ fertilizer also increased the proportion of soil macroaggregates $(>2 \mathrm{~mm})$ 
TABLE 3: Residual effects of applications of fresh and composted paper sludges, and $\mathrm{N}$ fertilizer on soil bulk density, nitrogen and carbon contents, $\mathrm{C} / \mathrm{N}$ ratio, and $\mathrm{C}\left(\mathrm{Mg} \mathrm{ha}^{-1}\right)$ at $0-10-\mathrm{cm}$ soil layer in 2004.

\begin{tabular}{|c|c|c|c|c|c|}
\hline Treatments & $\begin{array}{l}\text { Bulk density } \\
\mathrm{g} \mathrm{cm}^{-3}\end{array}$ & $\begin{array}{c}\text { Total N } \\
\mathrm{g} \mathrm{kg}^{-1}\end{array}$ & $\begin{array}{c}\mathrm{C} \\
\mathrm{g} \mathrm{kg}^{-1}\end{array}$ & $\mathrm{C} / \mathrm{N}$ & $\begin{array}{c}\mathrm{C} \\
\mathrm{Mgha}^{-1}\end{array}$ \\
\hline \multicolumn{6}{|l|}{ Frequency (single application) } \\
\hline Control & 1.44 & 1.38 & 16.8 & 12 & 40.7 \\
\hline $\mathrm{N}$ fertilizer $\left(160 \mathrm{~kg} \mathrm{~N} \mathrm{ha}^{-1}\right)$ & 1.49 & 1.30 & 15.6 & 12 & 39.6 \\
\hline FDS & 1.44 & 1.50 & 20.7 & 14 & 50.3 \\
\hline CDS & 1.42 & 1.50 & 19.2 & 13 & 46.0 \\
\hline $\mathrm{FDS}+120 \mathrm{~kg} \mathrm{~N} \mathrm{ha}^{-1}$ & 1.47 & 1.42 & 19.0 & 13 & 47.4 \\
\hline $\mathrm{CDS}+120 \mathrm{~kg} \mathrm{Nha}^{-1}$ & 1.44 & 1.58 & 21.2 & 13 & 51.6 \\
\hline \multicolumn{6}{|l|}{ Frequency (triple application) } \\
\hline Control & 1.50 & 1.36 & 16.5 & 12 & 42.3 \\
\hline $\mathrm{N}$ fertilizer $\left(160 \mathrm{~kg} \mathrm{~N} \mathrm{ha}^{-1}\right)$ & 1.49 & 1.31 & 15.9 & 12 & 40.2 \\
\hline FDS & 1.39 & 1.59 & 21.9 & 14 & 51.4 \\
\hline CDS & 1.47 & 1.43 & 19.0 & 13 & 47.4 \\
\hline $\mathrm{FDS}+120 \mathrm{~kg} \mathrm{~N} \mathrm{ha}^{-1}$ & 1.43 & 1.43 & 19.2 & 13 & 46.4 \\
\hline $\mathrm{CDS}+120 \mathrm{~kg} \mathrm{Nha}^{-1}$ & 1.44 & 1.52 & 20.0 & 13 & 49.0 \\
\hline \multicolumn{6}{|l|}{ ANOVA F values } \\
\hline Treatments & 1.80 & $11.82^{* *}$ & $16.57^{* *}$ & $13.15^{* *}$ & $16.08^{* *}$ \\
\hline Frequency & 0.04 & 0.05 & 0.00 & 0.30 & 0.04 \\
\hline Treatments $\times$ Frequency & 1.58 & 1.05 & 0.55 & 0.40 & 0.53 \\
\hline \multicolumn{6}{|l|}{ Contrasts } \\
\hline (1) Control versus others & 1.11 & $7.04^{*}$ & $18.06^{* *}$ & $24.91^{* *}$ & $19.67^{* *}$ \\
\hline (2) $\mathrm{N}$ fert. versus FDS and CDS & $5.64^{*}$ & $38.84^{* *}$ & $51.44^{* *}$ & $30.61^{* *}$ & $49.50^{* *}$ \\
\hline (3) FDS versus CDS & 0.48 & 0.65 & 0.39 & $7.08^{*}$ & 0.12 \\
\hline (4) $\mathrm{FDS}^{\ddagger}$ versus $\mathrm{FDSN}^{\S}$ & 1.77 & $8.01^{*}$ & $8.62^{* *}$ & 3.09 & $6.30^{*}$ \\
\hline (5) $\mathrm{CDS}^{\Uparrow}$ versus $\mathrm{CDSN}^{\#}$ & 0.00 & $4.56^{*}$ & 4.02 & 0.06 & $4.94^{*}$ \\
\hline
\end{tabular}

$*{ }^{* *}=.05$ and .01 probability levels of statistically significant difference, respectively.

${ }^{\ddagger}$ FDS, ${ }^{\S}$ FDSN: fresh paper sludges alone or with $\mathrm{N}$ fertilizer, respectively.

"CDS, " CDSN: composted paper sludges alone or with $\mathrm{N}$ fertilizer, respectively.

and the mean-weight diameter of aggregates (Table 2; contrast 2), compared to the control. Availability of readily assimilable $\mathrm{N}$ from fertilizer may stimulate the growth and activity of soil microorganisms, such as fungi, which partly contribute to the formation and stabilization of soil aggregates [31], as do organic binding agents. This result is not in concordance with the findings of Lynch and Bragg [32], Bipfubusa et al. [10], and Nyiraneza et al. [4] who show that NPK fertilizer significantly reduced soil macroaggregates. However, Nyiraneza et al. [4] have demonstrated that only long-term $\mathrm{N}$ fertilizer applications reduce soil macroaggregates and the MWD of water-stable aggregates particularly in low residue organic systems.

Three successive applications of FDS and CDS did significantly change neither the proportion of soil macroaggregates nor the mean-weight diameter of aggregates, compared to their single addition (Table 2). This suggests that paper sludges and their composts had long-lasting effect on soil macroaggregate formation and stability.

Residual effects of these organic wastes on soil stable macroaggregates are of high interest, as a well-structured soil can ensure high yields through a better air and water infiltration, nutrient cycling and availability to crops, and soil protection against erodability $[17,33]$. Improvement of soil macroaggregation with addition of FDS or CDS is especially important in crop rotation system with low residue return to the soil [14] such as silage corn and cereal with residues exported. De-inking paper sludges used in this study and other paper sludges generally contain high level of ligninlike materials $[6,34]$ which are known to induce long-lasting effect on soil physical properties such as aggregate stability.

The soil bulk density in the $0-10-\mathrm{cm}$ soil layer was not significantly affected by the organic material applications compared to the control (Table 3 ). In the $10-20-\mathrm{cm}$ soil layer, the soil bulk density was higher in the control and the complete $\mathrm{N}$ fertilizer treatment, compared to the soils which received the FDS or CDS applications (Table 4; contrasts 1 and 2). This result could be explained by the low organic matter input in the control or in the $\mathrm{N}$ fertilizer treatment compared to treatments that included FDS or CDS. Decrease of soil bulk density after addition of organic materials has been also reported by Foley and Cooperband [5] and Shepherd et al. [35] due to the soil dilution. Decrease of soil bulk density could also be associated with the increase of macroaggregates following FDS or CDS additions to the soil (Table 2). 
TABLE 4: Residual effects of applications of fresh and composted paper sludge, and $\mathrm{N}$ fertilizer on soil bulk density, nitrogen and carbon contents, $\mathrm{C} / \mathrm{N}$ ratio, and $\mathrm{C}\left(\mathrm{Mg} \mathrm{ha}^{-1}\right)$ at $10-20-\mathrm{cm}$ soil layer in 2004.

\begin{tabular}{|c|c|c|c|c|c|}
\hline Treatments & $\begin{array}{c}\text { Bulk density } \\
\mathrm{g} \mathrm{cm}^{-3}\end{array}$ & $\begin{array}{l}\text { Total N } \\
\mathrm{g} \mathrm{kg}^{-1}\end{array}$ & $\begin{array}{c}\mathrm{C} \\
\mathrm{g} \mathrm{kg}^{-1}\end{array}$ & $\mathrm{C} / \mathrm{N}$ & $\begin{array}{c}\mathrm{C} \\
\mathrm{Mgha}^{-1}\end{array}$ \\
\hline \multicolumn{6}{|l|}{ Frequency (single application) } \\
\hline Control & 1.49 & 1.36 & 16.7 & 12 & 41.80 \\
\hline $\mathrm{N}$ fertilizer $\left(160 \mathrm{~kg} \mathrm{~N} \mathrm{ha}^{-1}\right)$ & 1.52 & 1.27 & 14.9 & 12 & 38.60 \\
\hline FDS & 1.45 & 1.53 & 20.4 & 13 & 50.23 \\
\hline CDS & 1.48 & 1.50 & 19.0 & 13 & 47.56 \\
\hline $\mathrm{FDS}+120 \mathrm{~kg} \mathrm{~N} \mathrm{ha}^{-1}$ & 1.50 & 1.47 & 20.0 & 13 & 50.97 \\
\hline $\mathrm{CDS}+120 \mathrm{~kg} \mathrm{Nha}^{-1}$ & 1.47 & 1.58 & 20.6 & 13 & 50.75 \\
\hline \multicolumn{6}{|l|}{ Frequency (triple application) } \\
\hline Control & 1.53 & 1.34 & 16.3 & 12 & 42.35 \\
\hline $\mathrm{N}$ fertilizer $\left(160 \mathrm{~kg} \mathrm{~N} \mathrm{ha}^{-1}\right)$ & 1.47 & 1.31 & 16.3 & 12 & 40.80 \\
\hline FDS & 1.41 & 1.57 & 22.6 & 14 & 54.02 \\
\hline CDS & 1.46 & 1.44 & 19.1 & 13 & 47.50 \\
\hline $\mathrm{FDS}+120 \mathrm{~kg} \mathrm{~N} \mathrm{ha}^{-1}$ & 1.43 & 1.49 & 20.6 & 14 & 49.91 \\
\hline $\mathrm{CDS}+120 \mathrm{~kg} \mathrm{~N} \mathrm{ha}^{-1}$ & 1.43 & 1.57 & 21.9 & 14 & 52.75 \\
\hline \multicolumn{6}{|l|}{ ANOVA F values } \\
\hline Treatments & 2.62 & $10.52^{* *}$ & $24.86^{* *}$ & $20.00^{* *}$ & $20.68^{* *}$ \\
\hline Frequency & 4.14 & 0.00 & $4.69^{*}$ & $16.51^{* *}$ & 1.72 \\
\hline Treatments $\times$ Frequency & 1.04 & 0.32 & 0.86 & 1.23 & 0.58 \\
\hline \multicolumn{6}{|l|}{ Contrasts } \\
\hline (1) Control versus others & $5.52^{*}$ & $10.55^{* *}$ & $31.56^{* *}$ & $31.71^{* *}$ & $24.21^{* *}$ \\
\hline (2) $\mathrm{N}$ fert. versus FDS and CDS & $4.94^{*}$ & $35.44^{* *}$ & $78.08^{* *}$ & $52.00^{* *}$ & $69.44^{* *}$ \\
\hline (3) FDS versus CDS & 0.28 & 0.09 & 2.14 & $12.39^{* *}$ & 2.02 \\
\hline (4) FDS $^{\ddagger}$ versus FDSN ${ }^{\S}$ & 1.68 & 1.92 & 2.88 & 0.70 & 1.06 \\
\hline (5) $\mathrm{CDS}^{\Uparrow}$ versus $\mathrm{CDSN}^{\#}$ & 0.67 & $4.61^{*}$ & $9.64^{* *}$ & 3.20 & $6.68^{*}$ \\
\hline
\end{tabular}

$* . * *=.05$ and .01 probability levels of statistically significant difference, respectively.

${ }^{\ddagger} \mathrm{FDS},{ }^{\S} \mathrm{FDSN}$ : fresh paper sludges alone or with $\mathrm{N}$ fertilizer, respectively.

${ }^{9} \mathrm{CDS},{ }^{\#} \mathrm{CDSN}$ : composted paper sludges alone or with $\mathrm{N}$ fertilizer, respectively.

3.2. Carbon and Nitrogen Contents. In both soil layers (010 and $10-20-\mathrm{cm}$ ), total $\mathrm{N}$ and $\mathrm{C}$ contents, $\mathrm{C} / \mathrm{N}$ ratio, and $\mathrm{C}$ content on hectare basis were higher with FDS or CDS applications alone or with supplemental $\mathrm{N}$ fertilizer, compared to the complete $\mathrm{N}$ fertilizer treatment and the control (Tables 3 and 4, contrasts 1 and 2). The effect of FDS and CDS application frequency was significant only for $\mathrm{C}$ contents and $\mathrm{C} / \mathrm{N}$ in the $10-20-\mathrm{cm}$ soil layer. Three yr applications of FDS and CDS in 2000, 2001, and 2002 produced higher soil C increase in the $10-20-\mathrm{cm}$ soil layer compared to their single application in 2000. This increase of the soil $\mathrm{C}$ content probably is due to higher amount of $\mathrm{C}$ applied with three successive applications of FDS and CDS compared to their single addition, and also to lower C decomposition in this soil layer (10-20-cm) compared to the surface layer (0-10-cm).

Single or triple applications of FDS and CDS produced on average a $25 \%$ increase of the soil $C$ content in $0-$ $10-\mathrm{cm}$ layer, compared to the control and the complete $\mathrm{N}$ fertilizer treatment. This increase was $25 \%$ and $31 \%$ for single and triple applications, respectively, in 10-20-cm depth. Although the total $\mathrm{C}$ applied with FDS was higher than with CDS, no difference was observed between FDS and CDS on $\mathrm{C}$ accumulation in both soil layers. In both soil layers, five yr application of $\mathrm{N}$ fertilizer at $160 \mathrm{~kg} \mathrm{~N} \mathrm{ha}^{-1}$ without organic amendments induced a significant decrease of the soil C content, compared to the unfertilized FDS and CDS treatment (Tables 3 and 4; contrast 2).

Results generally showed that applications of FDS or CDS may contribute to $\mathrm{C}$ accumulation and a subsequent improvement of soil fertility and structure, as reported by Darwish et al. [14] and Varvel [36]. However, the high accumulation of $\mathrm{C}$ in this clay loam following FDS or CDS applications may be due to the $\mathrm{C}$ protection from decomposition through aggregation and association with silt and clay particles [12] and might not be expected in coarse textured soils with low ability to protect newly-added $\mathrm{C}$ from mineralization [35]. The $\mathrm{C}$ accumulation in that soil may also be attributable to the high content of FDS and CDS in stable $\mathrm{C}$ with low decomposition rate. Paper sludges 
TABLE 5: Direct and residual effects of applications of fresh and composted paper sludges, and $\mathrm{N}$ fertilizer on yield and $\mathrm{N}$ uptake of silage corn (2001 to 2003) and barley (2004).

\begin{tabular}{|c|c|c|c|c|c|c|c|c|}
\hline \multirow[t]{5}{*}{ Treatments } & \multicolumn{8}{|c|}{ Growing seasons (year) } \\
\hline & 2001 & 2002 & 2003 & 2004 & 2001 & 2002 & 2003 & 2004 \\
\hline & \multicolumn{4}{|c|}{ Yields } & \multicolumn{4}{|c|}{$\mathrm{N}$ uptake } \\
\hline & \multicolumn{3}{|c|}{ Silage corn } & Barley & \multicolumn{3}{|c|}{ Silage corn } & Barley \\
\hline & \multicolumn{4}{|c|}{$\mathrm{Mgha}^{-1}$} & \multicolumn{4}{|c|}{$\mathrm{kg} \mathrm{ha}^{-1}$} \\
\hline \multicolumn{9}{|l|}{ Frequency (single application) } \\
\hline Control & 8.5 & 6.4 & 10.6 & 2.4 & 81.1 & 47.5 & 125 & 37.37 \\
\hline $\mathrm{N}$ fertilizer $\left(160 \mathrm{~kg} \mathrm{~N} \mathrm{ha}^{-1}\right)$ & 13.6 & 12.0 & 14.0 & 2.5 & 149.4 & 122.9 & 163 & 38.08 \\
\hline FDS & 11.1 & 8.9 & 14.4 & 2.8 & 118.5 & 78.5 & 173 & 43.51 \\
\hline CDS & 8.4 & 7.1 & 11.8 & 2.8 & 72.2 & 54.1 & 137 & 43.59 \\
\hline FDS $+120 \mathrm{~kg} \mathrm{~N} \mathrm{ha}^{-1}$ & 14.1 & 13.0 & 14.2 & 2.8 & 137.0 & 128.8 & 166 & 44.6 \\
\hline $\mathrm{CDS}+120 \mathrm{~kg} \mathrm{~N} \mathrm{ha}^{-1}$ & 13.2 & 11.8 & 13.9 & 3.1 & 117.4 & 104.6 & 164 & 47.3 \\
\hline \multicolumn{9}{|l|}{ Frequency (triple application) } \\
\hline Control & 8.8 & 7.0 & 12.4 & 2.4 & 88.8 & 55.6 & 139 & 37.13 \\
\hline $\mathrm{N}$ fertilizer $\left(160 \mathrm{~kg} \mathrm{~N} \mathrm{ha}^{-1}\right)$ & 14.7 & 12.4 & 13.6 & 2.3 & 166.5 & 128.7 & 163 & 34.37 \\
\hline FDS & 10.7 & 8.7 & 14.2 & 3.3 & 116.3 & 75.8 & 165 & 51.37 \\
\hline CDS & 8.5 & 7.3 & 13.4 & 2.8 & 74.9 & 59.8 & 151 & 43.9 \\
\hline FDS $+120 \mathrm{~kg} \mathrm{~N} \mathrm{ha}^{-1}$ & 14.5 & 12.5 & 14.1 & 3.1 & 144.5 & 123.4 & 164 & 48.56 \\
\hline $\mathrm{CDS}+120 \mathrm{~kg} \mathrm{~N} \mathrm{ha}^{-1}$ & 14.3 & 12.8 & 14.6 & 2.7 & 128.7 & 126.7 & 176 & 43.36 \\
\hline \multicolumn{9}{|l|}{ ANOVA $F$ values } \\
\hline Treatments & $37.0^{* *}$ & $45.1^{* *}$ & 1.16 & $3.96^{*}$ & $21.0^{* *}$ & $47.3^{* *}$ & 1.52 & 3.33 \\
\hline Frequency & 1.4 & 0.6 & 0.39 & 0.06 & 1.6 & 1.9 & 0.00 & 0.10 \\
\hline Treatments $\times$ Frequency & 0.4 & 0.4 & 0.39 & 0.97 & 0.2 & 0.9 & 1.22 & 0.74 \\
\hline \multicolumn{9}{|l|}{ Contrasts } \\
\hline (1) Control versus others & $54.6^{* *}$ & $78.9^{* *}$ & 0.01 & $5.92^{*}$ & $24.0^{* *}$ & $78.8^{* *}$ & 2.35 & $5.18^{*}$ \\
\hline (2) $\mathrm{N}$ fert. versus FDS and CDS & $20.7^{* *}$ & $17.7^{* *}$ & 0.00 & $12.19^{* *}$ & $31.9^{* *}$ & $32.2^{* *}$ & 0.02 & $10.35^{*}$ \\
\hline (3) FDS versus CDS & $11.3^{* *}$ & $6.1^{*}$ & 1.81 & 1.23 & $19.3^{* *}$ & $9.3^{* *}$ & 1.17 & 0.86 \\
\hline (4) $\mathrm{FDS}^{\ddagger}$ versus $\mathrm{FDSN}^{\S}$ & $29.2^{* *}$ & $46.1^{* *}$ & 0.03 & 0.21 & $5.5^{*}$ & $47.6^{* *}$ & 0.10 & 0.05 \\
\hline (5) $\mathrm{CDS}^{n}$ versus $\mathrm{CDSN}^{\#}$ & $69.8^{* *}$ & $76.7^{* *}$ & 3.93 & 0.26 & $25.0^{* *}$ & $68.4^{* *}$ & 3.96 & 0.18 \\
\hline
\end{tabular}

${ }^{*} .{ }^{* *}=.05$ and .01 probability levels of statistically significant difference, respectively.

${ }^{\ddagger}$ FDS, ${ }^{\S}$ FDSN: fresh paper sludges alone or with $\mathrm{N}$ fertilizer, respectively.

"CDS, "CDSN: composted paper sludges alone or with $\mathrm{N}$ fertilizer, respectively.

have high lignin content [6] that resist against mineralization and therefore contribute to increase the soil carbon content $[8,12]$.

3.3. Corn and Barley Yields and N Uptake. Results obtained in 2000 showed that the FDS and CDS applications with or without $\mathrm{N}$ fertilizer decreased silage corn yields and $\mathrm{N}$ uptake compared to the unamended, unfertilized control (data not presented). This is consistent with the findings of previous studies reporting a reduction in crop yields and $\mathrm{N}$ uptake following the application of organic wastes in the first growing seasons $[37,38]$. Silage corn yields and $\mathrm{N}$ uptake obtained in 2001 and 2002 in presence of FDS or CDS without supplemental mineral $\mathrm{N}$ were also lower than yields and $\mathrm{N}$ uptake found in treatments including $\mathrm{N}$ fertilizer application and FDS or CDS combined with reduced $\mathrm{N}$ rates (Table 5 , contrasts 2,4 , and 5 ). The low total
$\mathrm{N}$ contents in fresh sludges $\left(8-11 \mathrm{~g} \mathrm{~kg}^{-1}\right)$ and in composted sludges $\left(6-8 \mathrm{~g} \mathrm{~kg}^{-1}\right)$ combined with the relatively high C:N ratios $(>30)$ could have resulted in $\mathrm{N}$ immobilization and the subsequent reduced $\mathrm{N}$ availability to silage corn. Net $\mathrm{N}$ immobilization by soil microflora was expected, based on reports of Whitehead et al. [39] and Seneviratne [40] for organic materials with such $\mathrm{C}: \mathrm{N}$ ratios and $\mathrm{N}$ contents lower than $15 \mathrm{~g} \mathrm{~kg}^{-1}$.

Conversely, using paper sludges with low $\mathrm{C}: \mathrm{N}$ ratios (13 to 15) and high $\mathrm{N}$ levels, N'Dayegamiye et al. [6] found that applications of those organic materials alone at rates of 30 to $90 \mathrm{Mg} \mathrm{ha}^{-1}$ produced high grain corn yields and $\mathrm{N}$ uptake. However, as apparent $\mathrm{N}$ recoveries ranged from 10 to $25 \%$ depending of the types of paper sludges, N'Dayegamiye $[1,6]$ showed that their application to the soil produced corn maximum yields only when $\mathrm{N}$ fertilizer was supplemented at reduced rates. In this study, the application of FDS or 
CDS with reduced rate of $\mathrm{N}$ fertilizer $\left(120 \mathrm{~kg} \mathrm{ha}^{-1}\right)$ led to high silage corn yields and $\mathrm{N}$ uptake in 2001 and 2002 similar to those found for complete rate of $\mathrm{N}$ fertilizer $\left(160 \mathrm{~kg} \mathrm{ha}^{-1}\right)$ for silage corn. The increased silage corn yields and $\mathrm{N}$ uptake in presence of FDS or CDS combined with reduced $\mathrm{N}$ fertilizer could be explained by the improvement of the soil aggregation (Table 2) and also by the additional nutrients in the FDS and CDS (Table 1) that could lead to better plant nutrition. As found in this study, many other studies $[6,15,20,41]$ observed a synergy between organic matter amendments and $\mathrm{N}$ fertilizers that is attributed to the improvement of soil properties and $\mathrm{N}$ availability from fertilizer which stimulate crop growth and $\mathrm{N}$ nutrition. As shown by Barker [42], application of fresh organic materials with high $\mathrm{C}: \mathrm{N}$ ratios and composts with stable $\mathrm{N}$ should be supplemented with $\mathrm{N}$ to prevent $\mathrm{N}$ immobilization and the subsequent decrease of crop yield. Being readily available, nitrogen fertilizer meets the crop needs but also stimulates the organic material decomposition [18].

In 2001 and 2002, higher silage corn yields and $\mathrm{N}$ uptake were found for FDS compared to CDS (Table 5, contrast 3 ). That could be explained by the higher initial $\mathrm{N}$ content in the fresh materials compared to the composts, but also because the CDS contains stable $\mathrm{N}$ which is less available to crops.

The application of FDS and CDS were stopped in 2003 and 2004 to assess their residual effects on silage corn and barley yields and $\mathrm{N}$ uptake. During these two years, all plots with FDS or CDS received reduced $\mathrm{N}$ rate (120 kg ha ${ }^{-1}$ ) for corn in 2003 and $60 \mathrm{~kg} \mathrm{ha}^{-1}$ for barley in 2004 in order to sustain crop yields (Table 5). The soils with FDS or CDS were compared with those which received the full rate of $\mathrm{N}$ fertilizer $\left(90 \mathrm{~kg} \mathrm{Nha}^{-1}\right)$ for barley and $160 \mathrm{~kg} \mathrm{Nha}^{-1}$ for corn. Silage corn yields and $\mathrm{N}$ uptake obtained in 2003 in the recommended $\mathrm{N}$ fertilizer treatment ( $160 \mathrm{~kg} \mathrm{Nha}^{-1}$ ) were not significantly different from those produced in soils previously amended with FDS or CDS with reduced $\mathrm{N}$ rate $\left(120 \mathrm{~kg} \mathrm{Nha}^{-1}\right)$ (Table 5 ; contrast 2 ). In addition, barley yields and $\mathrm{N}$ uptake were higher in 2004 in soils which received FDS or CDS with reduced $\mathrm{N}$ rate $\left(60 \mathrm{~kg} \mathrm{~N} \mathrm{ha}^{-1}\right)$ compared to the recommended $\mathrm{N}$ fertilizer rate $\left(90 \mathrm{kgNha}^{-1}\right)$ (Table 5 , contrast 2 ). The high crop yields recorded two years after the cessation of FDS and CDS applications could be explained by the improvement of soil properties and productivity (e.g., soil aggregation and density, C content) (Tables 2, 3, and 4).

The FDS and CDS application frequency effect on crop yields and $\mathrm{N}$ uptake was not significant (Table 5) which suggests that the residual effect was not mainly due to nutrient accumulation, but also to the improvement in soil properties which positively affect plant root growth and nutrients absorption. This is an interesting result, as regular application of FDS or CDS is not practicable because of the high cost associated on the transport and application of these organic wastes. The insignificant effect of the FDS and CDS application frequency is also consistent with previous studies that have shown that the residual effects of fresh and composted manure applications on crop (i.e., millet, rye forage, and corn) yields and soil properties can persist for several years after the applications have stopped $[43,44]$. The high crop yields obtained in soils which received the FDS or CDS may be attributable to the long-lasting effects of those organic materials on the soil structure.

\section{Conclusion}

The application of fresh and composted paper sludges under silage corn and barley rotation increased the soil macroaggregates and the MWD of soil water-stable aggregates, reduced the soil density, and increased the soil total $\mathrm{N}$ and $\mathrm{C}$ contents. Repeated application of $\mathrm{N}$ fertilizer alone in a clay loam increased soil water-stable macroaggregates, but tended to decrease the soil $\mathrm{C}$ and $\mathrm{N}$ content compared to the unfertilized control. Even if the paper sludges used had low $\mathrm{N}$ content and high $\mathrm{C}: \mathrm{N}$ ratios (25 to 40 ), our results showed that, except in the first year of their application, their additions produced high silage corn yields and $\mathrm{N}$ uptake when combined with reduced $\mathrm{N}$ fertilizer $\left(120 \mathrm{~kg} \mathrm{Nha}^{-1}\right)$. Moreover, the effects of fresh and composted paper sludges on soil productivity were significant a couple of years after their cessation (residual effect). This finding is interesting as a regular application of FDS and CDS may present a high cost. This investigation showed that the agronomic benefits of the FDS and CDS were mainly related to their capacity to enhance soil physical properties.

\section{Abbreviations}

CDS: Composted paper sludges

CDSN: Composted paper sludges supplemented with reduced $\mathrm{N}$ fertilizer

FDS: $\quad$ Fresh paper sludges

FDSN: Fresh paper sludges supplemented with reduced $\mathrm{N}$ fertilizer

MWD: Mean weight diameter of soil aggregates

Single: One application of FDS and CDS in 2000

Triple: Three successive applications of FDS and CDS in 2000, 2001, and 2002.

\section{Acknowledgments}

This research was supported by the Research Institute for Agri-Environnement. The author thanks Dr. Judith Nyiraneza for reviewing the early draft of this paper. Special thanks to Michel Noël and Jean Marie Noël for their assistance in plot maintenance and data collection.

\section{References}

[1] A. N'Dayegamiye, "Soil properties and crop yields in response to mixed paper mill sludges, dairy cattle manure, and inorganic fertilizer application," Agronomy Journal, vol. 101, no. 4, pp. 826-835, 2009.

[2] A. Fierro, D. A. Angers, and C. J. Beauchamp, "Decomposition of paper de-inking sludge in a sandpit minesoil during its revegetation," Soil Biology and Biochemistry, vol. 32, no. 2, pp. 143-150, 2000.

[3] K. M. Hati, A. Swarup, B. Mishra, et al., "Impact of longterm application of fertilizer, manure and lime under intensive 
cropping on physical properties and organic carbon content of an Alfisol," Geoderma, vol. 148, no. 2, pp. 173-179, 2008.

[4] J. Nyiraneza, M. H. Chantigny, A. N’Dayegamiye, and M. R. Laverdière, "Dairy cattle manure improves soil productivity in low residue rotation systems," Agronomy Journal, vol. 101, no. 1, pp. 207-214, 2009.

[5] B. J. Foley and L. R. Cooperband, "Paper mill residuals and compost effects on soil carbon and physical properties," Journal of Environmental Quality, vol. 31, no. 6, pp. 20862095, 2002.

[6] A. N'Dayegamiye, "Mixed paper mill sludge effects on corn yield, nitrogen efficiency, and soil properties," Agronomy Journal, vol. 98, no. 6, pp. 1471-1478, 2006.

[7] M. V. Cheshire and S. J. Chapman, "Influence of the N and $\mathrm{P}$ status of plant material and of added $\mathrm{N}$ and $\mathrm{P}$ on the mineralization of $\mathrm{C}$ from ${ }^{14} \mathrm{C}$-labelled ryegrass in soil," Biology and Fertility of Soils, vol. 21, no. 3, pp. 166-170, 1996.

[8] N. Z. Lupwayi, G. W. Clayton, J. T. O’Donovan, K. N. Harker, T. K. Turkington, and W. A. Rice, "Decomposition of crop residues under conventional and zero tillage," Canadian Journal of Soil Science, vol. 84, no. 4, pp. 403-410, 2004.

[9] M. H. Chantigny, D. A. Angers, D. Prévost, L.-P. Vézina, and F.-P. Chalifour, "Soil aggregation and fungal and bacterial biomass under annual and perennial cropping systems," Soil Science Society of America Journal, vol. 61, no. 1, pp. 262-267, 1997.

[10] M. Bipfubusa, D. A. Angers, A. N'Dayegamiye, and H. Antoun, "Soil aggregation and biochemical properties following the application of fresh and composted organic amendments," Soil Science Society of America Journal, vol. 72, no. 1, pp. 160-166, 2008.

[11] C. Nduwamungu, L. E. Parent, J. Fortin, and L. Khiari, "Relationship between biological stability and net N mineralization of organic amendments and fertilizers," in Proceedings of International Conferences on Moving Forward Wasterwater Biosolids Sustainability: Technical, Managerial, and Public Synergy, pp. 439-445, Water Association, Moncton, Canada, June 2007.

[12] J. Six, R. T. Conant, E. A. Paul, and K. Paustian, "Stabilization mechanisms of soil organic matter: implications for Csaturation of soils," Plant and Soil, vol. 241, no. 2, pp. 155-176, 2002.

[13] A. S. Grandya, G. A. Porter, and M. S. Erichb, "Organic amendment and rotation crop effects on the recovery of soil organic matter and aggregation in potato cropping systems," Soil Science Society of America Journal, vol. 66, no. 4, pp. 13111319, 2002.

[14] O. H. Darwish, N. Persaud, and D. C. Martens, "Effect of longterm application of animal manure on physical properties of three soils," Plant and Soil, vol. 176, no. 2, pp. 289-295, 1995.

[15] M. M. Abdallahi and A. N'Dayegamiye, "Effects of green manures on soil physical and biological properties and on wheat yields and $\mathrm{N}$ uptakeEffets de deux incorporations d'engrais verts sur le rendement et la nutrition en azote du blé (Triticum aestivum L.), ainsi que sur les propriétés physiques et biologiques du sol," Canadian Journal of Soil Science, vol. 80, no. 1, pp. 81-89, 2000.

[16] M. J. Kirchner, A. G. I. I. Wollum, and L. D. King, "Soil microbial populations and activities in reduced chemical input agroecosystems," Soil Science Society of America Journal, vol. 57, no. 5, pp. 1289-1295, 1993.

[17] M. R. Carter, "Soil quality for sustainable land management: organic matter and aggregation interactions that maintain soil functions," Agronomy Journal, vol. 94, no. 1, pp. 38-47, 2002.
[18] P. Bhattacharyya, A. Chakraborty, B. Bhattacharya, and K. Chakrabarti, "Evaluation of MSW compost as a component of integrated nutrient management in wetland rice," Compost Science and Utilization, vol. 11, no. 4, pp. 343-350, 2003.

[19] F. R. Magdoff and J. F. Amadon, "Yield trends and soil chemical changes resulting from manure applications to continuous corn," Agronomy Journal, vol. 72, pp. 161-164, 1980.

[20] C. A. Palm, J. K. Myers, and S. M. Nandwa, "Combined use of organic and inorganic nutrient sources for soil fertility maintenance and replenishment," in Replenishing Soil Fertility in Africa, R. J. Buresh, P. A. Sanchez, and F. Calhoun, Eds., SSSA Special Publication number 51, pp. 193-217, Soil Science Society of America, 1997.

[21] R. A. Isaac and W. C. Johnson, "Determination of total nitrogen on plant tissues using BD-40 digestion," Journal of the Association of Official Analytical Chemists, vol. 50, pp. 98-100, 1980.

[22] J. E. Richards, "Chemical characterization of plant tissue," in Soil Sampling and Methods of Analysis, M. R. Carter, Ed., pp. 115-139, Lewis, Boca Raton, Fla, USA, 2001.

[23] A. Mehlich, "Mehlich 3 soil test extractant: a modification of Mehlich 2 extractant," Communications in Soil Science \& Plant Analysis, vol. 15, no. 12, pp. 1409-1416, 1984.

[24] W. D. Kemper and R. C. Rosenau, "Aggregate stability and size distribution," in Methods of Soil Analysis. Part 1. Physical and Mineralogical Methods, A. L. Page, Ed., vol. 9 of Agronomy Monograph, ASA, Madison, Wis, USA, 1986.

[25] R. J. Haynes and M. H. Beare, "Influence of six crop species on aggregate stability and some labile organic matter fractions," Soil Biology and Biochemistry, vol. 29, no. 11-12, pp. 16471653, 1997.

[26] J. A. McKeague, Manual of Soil Sampling and Method of Analysis, Canadian Society of Soil Science, Ottawa, Canada, 2nd edition, 1978.

[27] SAS Institute, SAS for Windows, SAS, Cary, NC, USA, 2001.

[28] M. H. Chantigny, D. A. Angers, and C. J. Beauchamp, "Aggregation and organic matter decomposition in soils amended with de-inking paper sludge," Soil Science Society of America Journal, vol. 63, no. 5, pp. 1214-1221, 1999.

[29] M. Bipfubusa, A. N’Dayegamiye, and H. Antoun, "Effets de boues mixtes de papetières fraîches et compostées sur l'agrégation du sol, l'inclusion et la minéralisation du C dans les macro-agrégats stables à l'eau," Canadian Journal of Soil Science, vol. 85, no. 1, pp. 47-55, 2005.

[30] K. Chaney and R. S. Swift, "The influence of organic matter on aggregate stability in some British soils," Journal of Soil Science, vol. 35, no. 2, pp. 223-230, 1984.

[31] J. M. Tisdall and J. M. Oades, "Organic matter and waterstable aggregates in soils," Journal of Soil Science, vol. 33, no. 2, pp. 141-163, 1982.

[32] J. M. Lynch and E. Bragg, "Microorganisms and soil aggregate stabililty," Advanced Soil Science, vol. 2, pp. 133-171, 1985.

[33] J. M. Oades, "Soil organic matter and structural stability: mechanisms and implications for management," Plant and Soil, vol. 76, no. 1-3, pp. 319-337, 1984.

[34] M. H. Chantigny, D. A. Angers, and C. J. Beauchamp, "Decomposition of de-inking paper sludge in agricultural soils as characterized by carbohydrate analysis," Soil Biology and Biochemistry, vol. 32, no. 11-12, pp. 1561-1570, 2000.

[35] M. A. Shepherd, R. Harrison, and J. Webb, "Managing soil organic matter-implications for soil structure on organic farms," Soil Use and Management, vol. 18, pp. 284-292, 2002. 
[36] G. E. Varvel, "Soil organic carbon changes in diversified rotations of the Western Corn Belt," Soil Science Society of America Journal, vol. 70, no. 2, pp. 426-433, 2006.

[37] P. R. Warman and J. M. Cooper, "Fertilization of a mixed forage crop with fresh and composted chicken manure and NPK fertilizer: effects on dry matter yield and soil and tissue N, P and K," Canadian Journal of Soil Science, vol. 80, no. 2, pp. 337-344, 2000.

[38] P. R. Warman and J. M. Cooper, "Fertilization of a mixed forage crop with fresh and composted chicken manure and NPK fertilizer: effects on soil and tissue $\mathrm{Ca}, \mathrm{Mg}, \mathrm{S}, \mathrm{B}, \mathrm{Cu}, \mathrm{Fe}$, Mn and Zn," Canadian Journal of Soil Science, vol. 80, no. 2, pp. 345-352, 2000.

[39] D. C. Whitehead, A. W. Bristow, and B. F. Pain, "The influence of some cattle and pig slurries on the uptake of nitrogen by ryegrass in relation to fractionation of the slurry N," Plant and Soil, vol. 117, no. 1, pp. 111-120, 1989.

[40] G. Seneviratne, "Litter quality and nitrogen release in tropical agriculture: a synthesis," Biology and Fertility of Soils, vol. 31, no. 1, pp. 60-64, 2000.

[41] A. N'Dayegamiye and T. S. Tran, "Effects of green manures on soil organic matter and wheat yields and N nutrition," Canadian Journal of Soil Science, vol. 81, no. 4, pp. 371-382, 2001.

[42] A. V. Barker, "Composition and use of compost," in Agricultural Uses of by-Products and Wastes, J. E. Rechcigl and H. C. MacKinnon, Eds., pp. 140-162, American Chemical Society, Washington, DC, USA, 1997.

[43] L. M. Mugwira, "Residual effects of dairy cattle manure on millet and rye forage and soil properties," Journal of Environmental Quality, vol. 8, no. 2, pp. 251-255, 1979.

[44] B. Eghball, D. Ginting, and J. E. Gilley, "Residual effects of manure and compost applications on corn production and soil properties," Agronomy Journal, vol. 96, no. 2, pp. 442-447, 2004. 


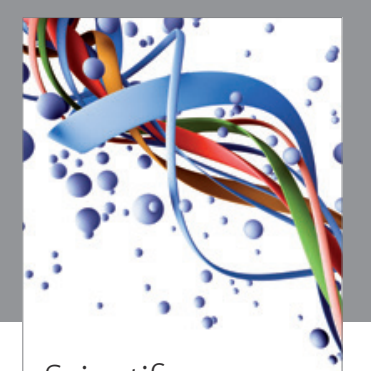

Scientifica
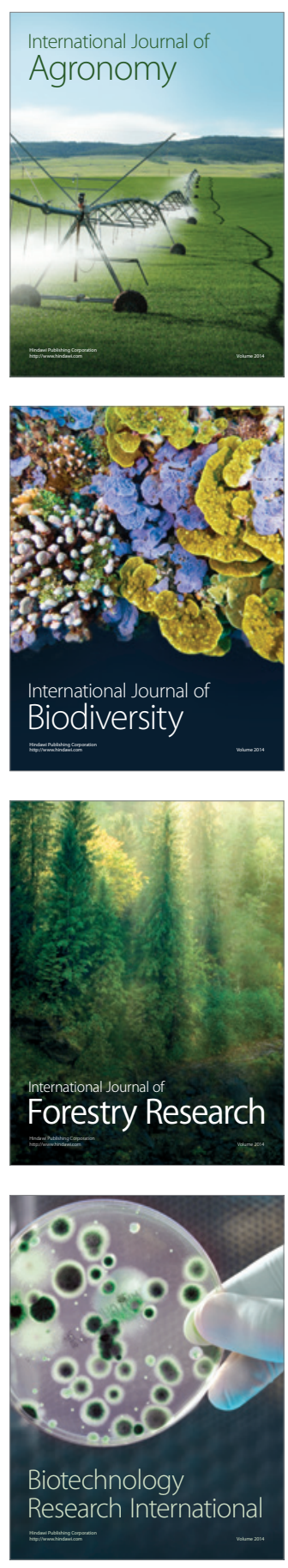
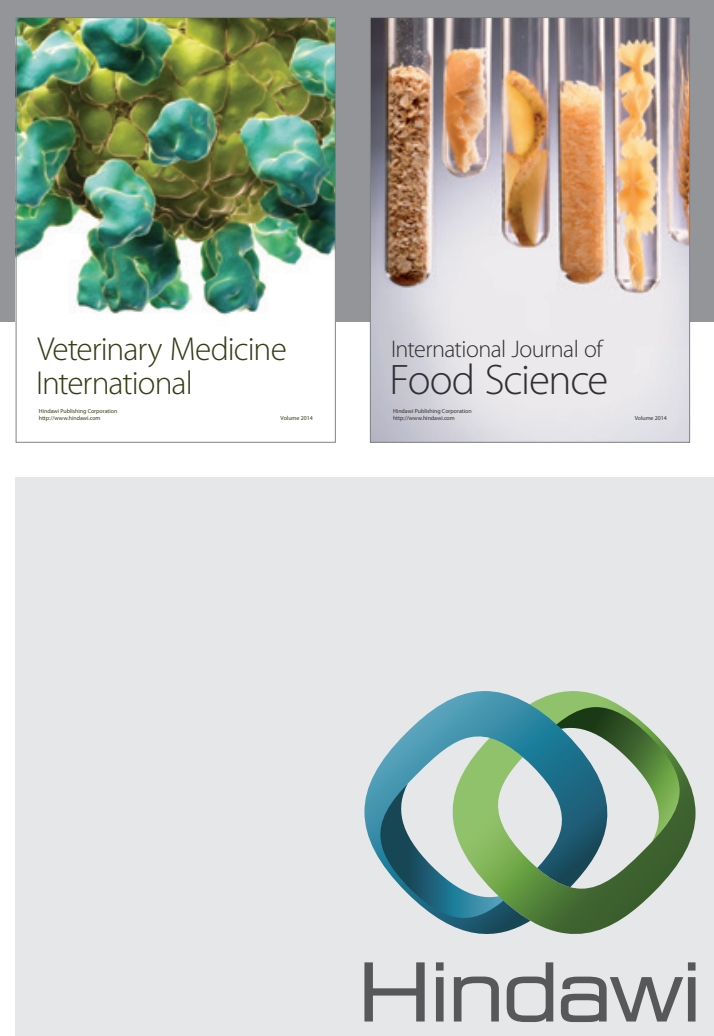

Submit your manuscripts at

http://www.hindawi.com
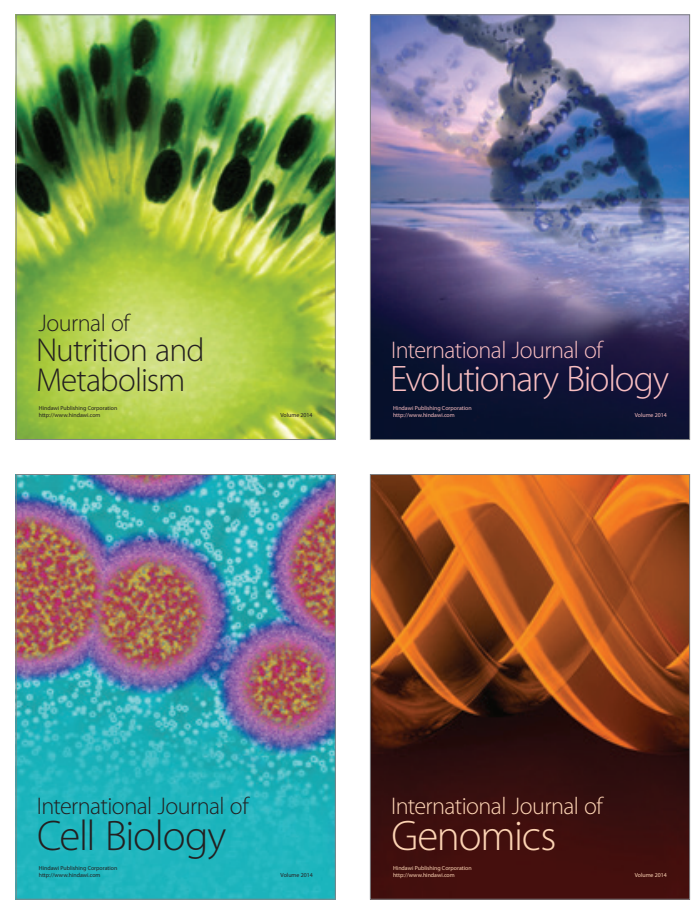
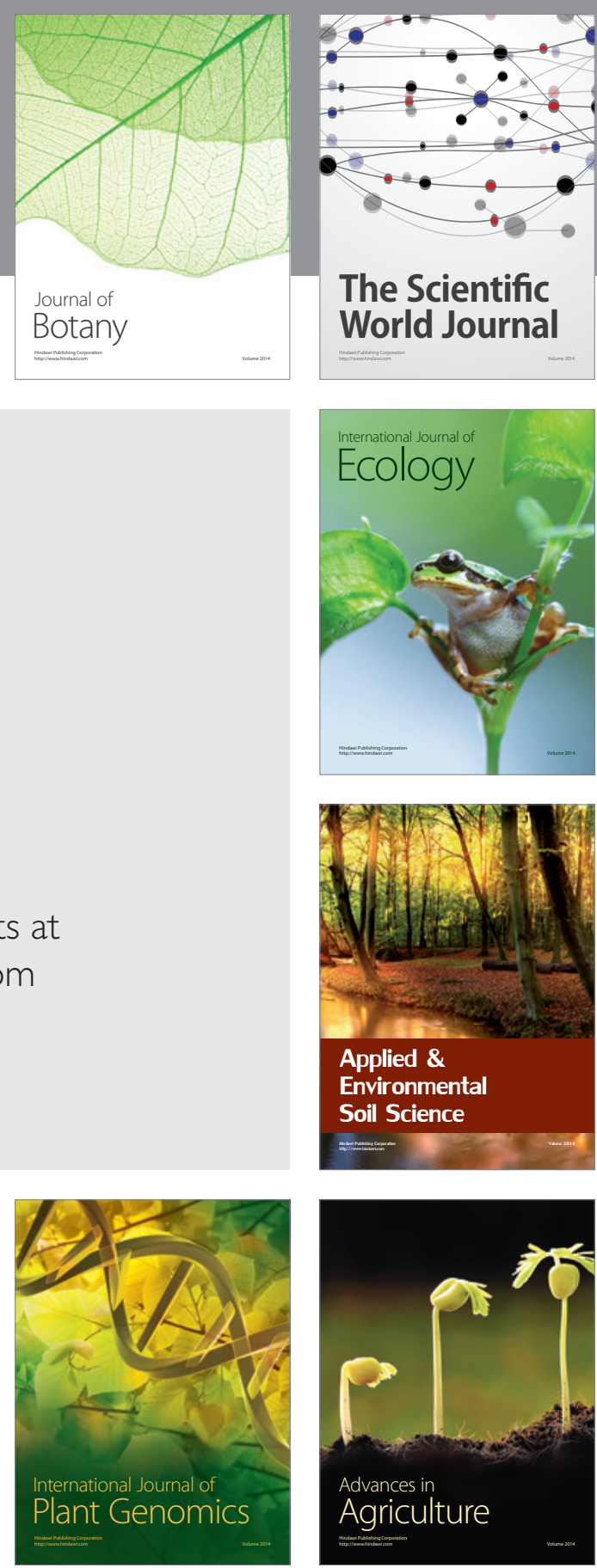

The Scientific World Journal
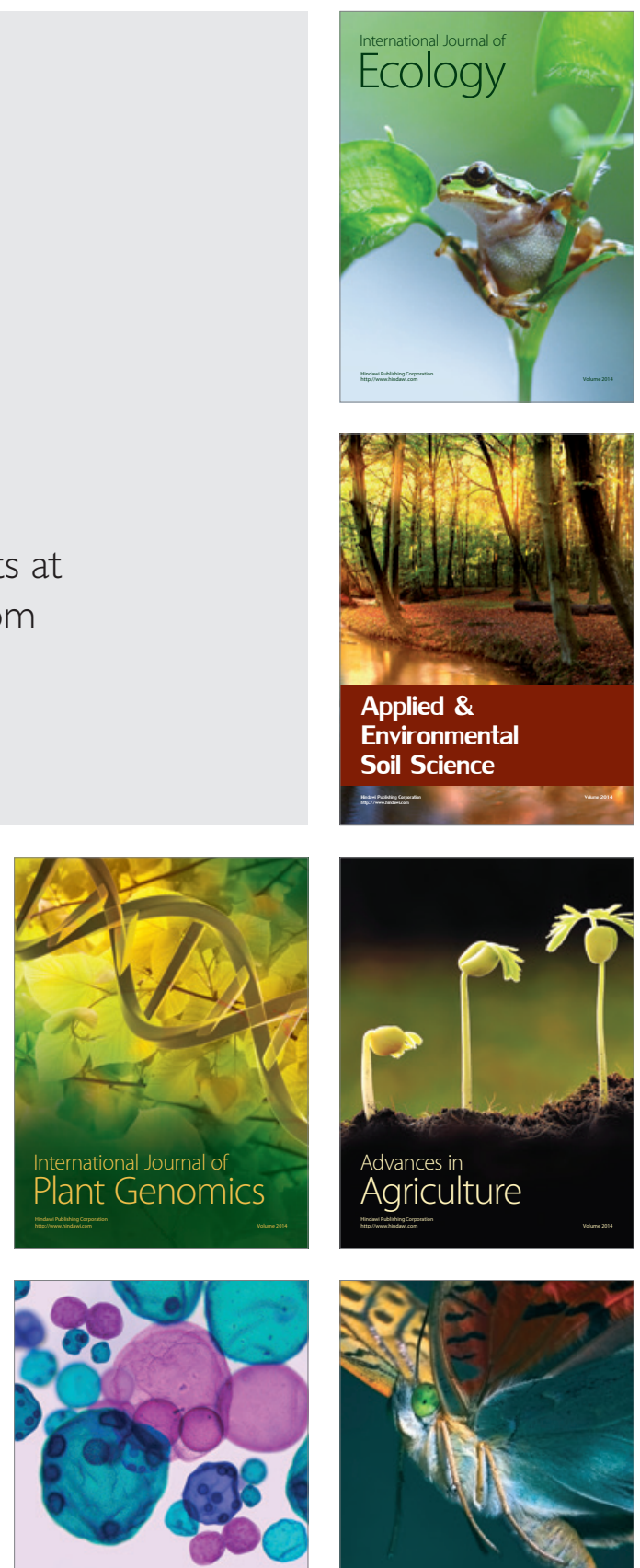

International Journal of Microbiology

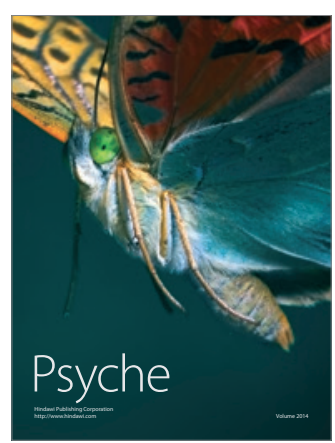

